\title{
理科が苦手な先生の心を どうつかむか
}

永山國昭・佐藤年緒

$\lceil 21$ 世紀の科学技術リテラシー像〜豊かに生 きるための智〜プロジェクト」の報告書を活用 し、広く国民全体のリテラシー向上にどうむす びつけていくのか。この問題に関しては科学技 術振興機構(JST)での試み、科学教育誌『Science Window』の創刊と普及が参考になると思われ るので紹介したい。

この雑誌は、理科を苦手とする学校の先生自 身に「科学するこころ」を育んでもらうことを 狙いとしている。いわば、「科学技術の智の普 及」の教育現場でのパイロット事業である。さ らに『Science Window』は先行事例になると いうだけでなくそれ自体がコミュニケーショ ン媒体として智の普及活動の一端を担えるか もしれない。こうした背景のもと、『Science Window』編集委員会 (現在Science Window 委員会）委員長永山國昭とJSTメディア課で編 集長佐藤年緒が本稿を共同で執筆した。
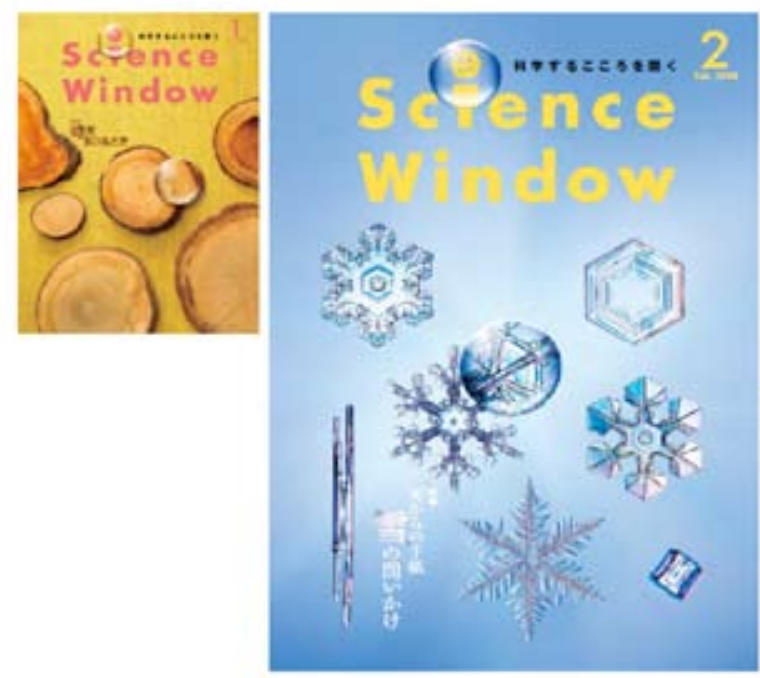

\section{子どもの疑問をともに考える}

「智のプロジェクト」は 2030 年までの 20 年余 りの間に、幼児から成人までの各発達段階に応 じて科学リテラシーを定着・普及させることを 目標にしている。ではどのような層に働き掛け ることが効果的だろうか。

教育現場という社会の部分空間を扱う 『Science Window』ではメインターゲットを、 小学校の先生としている。子どもたちにとって 理科は関心や興味がある科目である。一方、理 科を教えることに苦手意識を持つ小学校の先 生が少なくない。JSTの理科教育支援センター と国立教育政策研究所が共同で実施した調査 (2008年8月) によると、小学校で理科の指導 を「苦手・やや苦手」とする教員は50\%あっ た。まさに先生達の科学リテラシー向上が急務 なのである。

では、苦手な先生にどうしたら科学を好きに するきっかけを与えられるのか。編集委員会で 明らかになったことは、子どもの「なぜ」とい う問いに先生が一緒になって答えていくこと の大切さである。

「子どもの発する問いは、答え るのが非常に難しい。例えば『空 はなぜ青いのか』『葉っぱはなぜ 緑か』といった問いに、きちっと 答えようとすると、ひとつの答え では済まない。自然科学は、こう 
した未分化で根源的な問い掛けをいろいろな 学問領域に分化させることによって答えやす くしていくプロセスです。物理学的な答え、化 学的な答え、生物学的な答えといったように限 定して問題を細分化していく。それを全部答え ようとしたら、それこそ一冊の本になってしま う。しかし、こうした問いを先生も逃げずに受 け止めて、一緒に解き続けることはできる。そ の大切さを伝えたい」(永山）という考えから である。

\section{日常生活とのつながりから}

つまり、大人も一緒に「なぜだろう」という 問いを発し、子どもと一緒に考えていけば科学 好きに自然となると考える。しかも自然の美し さや不思議さ、驚きを感じる心、いわゆる「セ ンス・オブ・ワンダー」を育めるように、写真 やデザインで美しさと驚きに配慮した。

このほか、(1)他の教科（例えば国語、古典、 保健・体育、音楽、美術、社会）の入り口から も科学の世界に近づく(2)家庭の電気製品など 日常生活から現代の科学技術の成果を考える (3)科学者や科学を伝える人をいきいきと描く (4)古来の日本人の自然観と現代の科学的な見 方のつながりを考える(5)実験への初歩的なア ドバイスをするーといった点も編集方針に挙 げている。毎号の特集では、子どもの素朴な疑 問を最初のページで投げ掛けて、さまざまな視

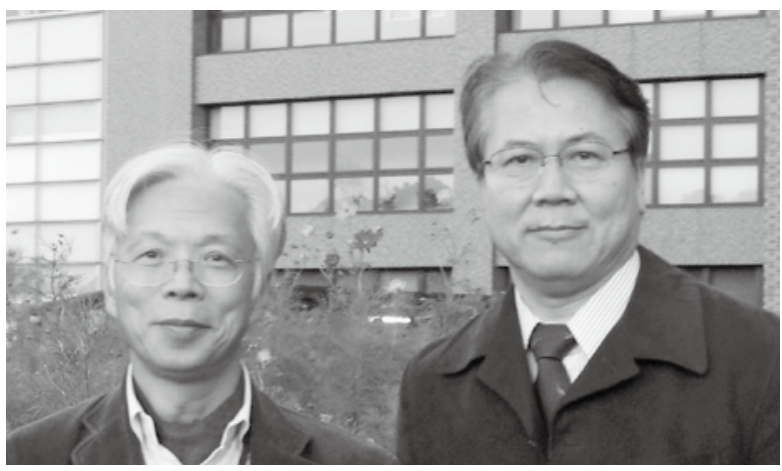

\section{PROFILE}

永山國昭

(ながやま くにあき)

日本学術会議連携会員、自然科 学研究機構岡崎統合バイオサイエ ンスセンター教授、「科学技術の 智」プロジェクト企画推進会議委員 専門：生物物理学、分子生物学、 細胞生物学

\section{PROFILE}

佐藤年緒

(さとう としお)

科学技術振興機構JSTメディア 課『Science Window』編集長
点からそれに答えるような構成にしている。

創刊号から 2 年経って、雑誌は都道府県、市 町村の教育委員会に理解と協力をいただきな がら配布し、全国の小中高校の $95 \%$ に当たる 3 万 7000 校に 2 部ずつ無料で届くようになった。 学校内に届く数ある雑誌のなかでも、美しい表 紙やデザインなどに、先生だけでなく子どもも 関心を寄せて、愛読者も増えてきているという。 昨年 12 月に小中学校の教員（理科を教えてい ない教員を含む）に対する読者アンケートを 行ったところ、小中学校とも全体の9割の先生 から「自分が理科・科学技術に親しむことに役 立つ」との評価を得た。理科に苦手意識を持つ

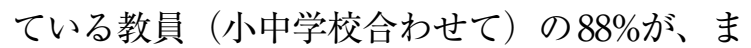
た小学校で理科を教えているものの苦手意識 を持っている教員の $93 \%$ 、「理科・科学技術 に親しむことに役立つ（「どちらかといえば」 を含む)」と回答した。 


\section{【読者の回答例】}

「Science Window」は、あなたが理科・科学技術に親しむことに役立つと思いますか。

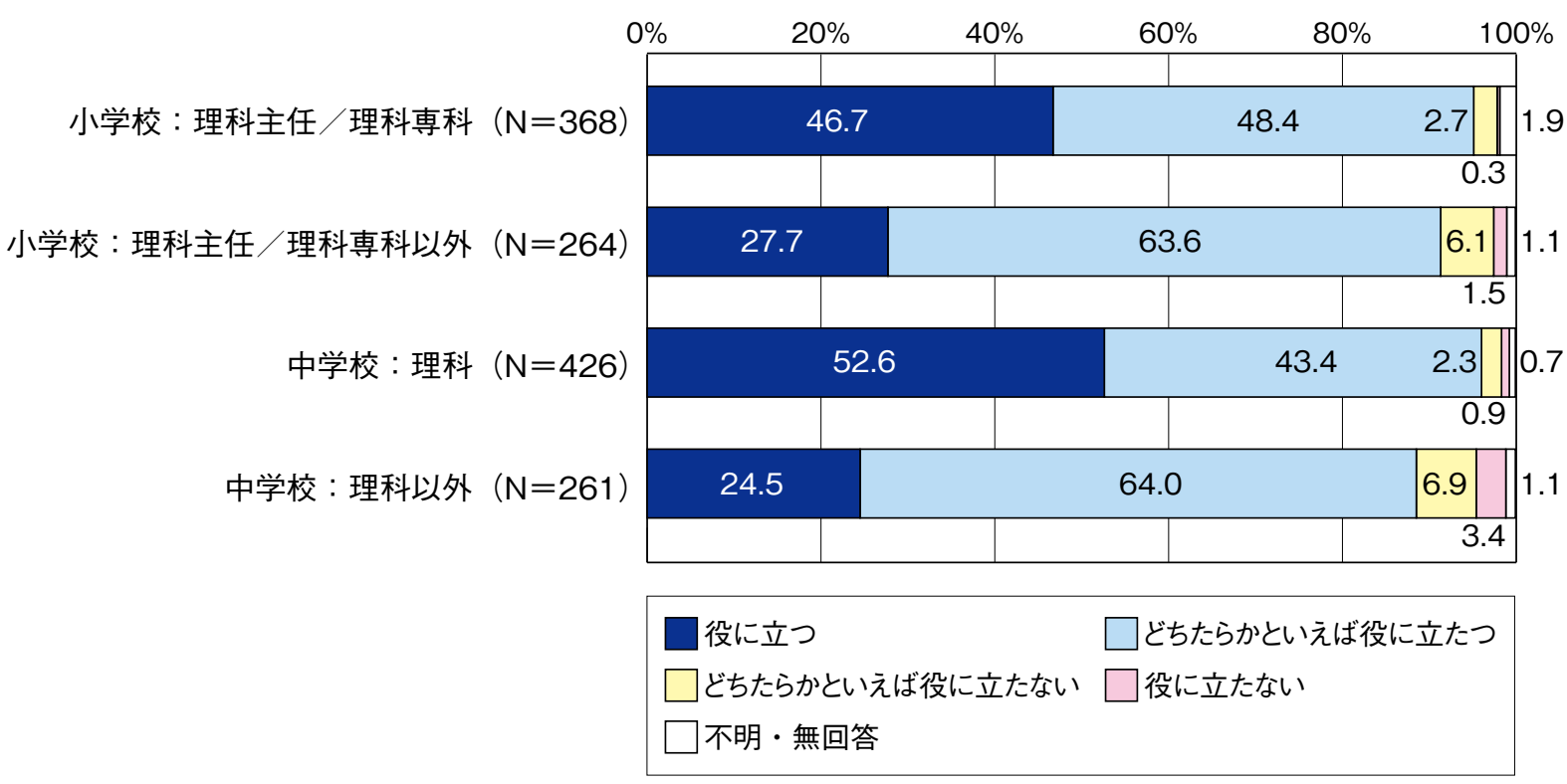

一般的に中学、高校で理科を教えている理科 担当教員は、小学校の教員に比べれば理科が得 意である。とはいえ、当誌が大事だと考えてい る“子どもが発するような”根本的な問いは、 理科担当教員にも改めて科学するこころを思 い出させるはずである。なぜなら根本的問いは 物理、化学、生物、地学といった教科の専門に とどまらない大きな広がりを持っているから である。その意味で理科以外の先生からの反応、 「自分自身の教科と理科とのつながりが見出せ そう」との感想は本雑誌の核心にせまっている。 自由回答の記述では、例えば「身近な自然現象 を分かりやすく解説されている」「現代の科学、 科学技術の紹介をするのに、そう長くない文章 で書かれており、生徒に対しても、多少の解説
を加えれば、理解できる内容も多々ある」といっ た感想が寄せられている。

\section{科学者との距離を埋める}

『Science Window』編集者は必ずしも科学の 専門家ではない。その編集者の目で、智のプ ロジェクトの報告書を読むと、一般の人が理解 できるように表現されているかどうか、さらに 他の科学の専門家にすら理解しにくい言葉に なっていないだろうか、と気になる。いずれも 多数の読者に検証してもらうことが必要に思 える。科学者による科学者のための報告書では なく、「科学が苦手な人にも読まれるための言 語」での表現方法がほしい。 
また報告書の個別的記事を誰が書いたのか わからないという問題がある。記事に筆者名が ない辞典的表記は教科書的で魅力がない。科学 的営みも科学的記述も個人の姿が見えること によって親しみが増す。これは科学コミュニ ケーションの双方向性という根幹にかかわる ことで『Science Window』も常に心がけてい ることである。執筆いたたくくしっかりしたサイ エンスライターの名前も記入し、取材者の見方 が入っていることを明確にしている。このよう な工夫も参考にしてもらいながら、この報告書 自体を国民と共に育てていく姿勢が大事であ ろう。

報告書では、7つの分野の個別の領域の紹介 だけでなく、現代の社会に緊急性があり関心の 高い問題として、「水」、「食料」「「エネルギー」、 「地球と人間圈」の 4 つの話題を提供している。 この4テーマについて、特定の分野だけでなく 「横串を通す」形でまとめてあり、多角的な視 点から読み応えがある。いずれも政治、経済に も大きく関わる問題だが、政治的、経済的ある いは経営的判断については「抑制的に記述して いる」としたうえ、「読者一人ひとりが的確に 判断していただきたい」と、問題解決の策を考 える上では、いわば読者を突き放している記述 になっている。例えば「水」のテーマでは、水 の物理的な性質や文化との関係などを記述し ているが、水問題は国や国内の地域によっても 問題の生じ方は異なるし、政策当事者か、生活 者かによって解決の方法も異なる。実際にどの
立場でこの問題の解決をするのか、具体的に関 わり合うことによって初めて生きた知識にな るのだろう。こうした困難な問題こそこの報告 書を国民とともに育てるプロセスの中で深め られて行くものと期待される。

\section{大人が生涯学べる道筋を}

報告書第6章「将来へ：科学技術の智の継承 と共有」の「学ぶとは」（p.205）のなかで、近 年の認知心理学の立場から新しい学習観に触 れている。そのなかで、「人間の学習は『知識 の獲得』という個人的な営みではなくて、対話 やコミュニケーションから生まれるものであ り、そのときの状況や文脈とは切り離されない」 として「すでに確立された知識を理解し、記憶 するのではなく、問題や関心を共有し、解決 しょうと共通の言葉で話すことによって共同 体が構築され、学びあいの場が生じる」ことの 重要性を紹介している。この考え方はまさしく 先生が子供とともに考える『Science Window』 の立場であり「科学技術の智」も読者と科学者 との間で、共通の学びの場を作り出すことが必 要だろう。

このリテラシーは、将来の 30 歳の大人が身 に付けるべきこととして提案されている。科学 技術が私たちの生活や文化にまで関わりを深 める将来において「最低限身に付けるべき素養」 は、知識というより、生涯を通じて学び続ける 対象である。そのためには科学的な考え方、科 
学するこころを身に付けることが重要と思わ れる。

報告書には「科学の研究を駆動してきたのは 尽きることのない好奇心である。（略）自然界 の事物・現象に対する素朴な驚きが『なぜ』と いう疑問を生み、それを探求するための方法を 模索する。そうした好奇心、豊かな感性を養 い、科学的探究に導くことは、大人たちに課せ られた大きな責務である。そのためには、大人 自身が、好奇心を持ち続けることが大切である」 （p.13-14）は、まさに『Science Window』が 目指すものである。

大人自身が「なぜ」と問え、知っていく道筋 の工夫が必要だろう。これまでの取材経験から、 その科学者が一級であればあるほど、現在の科 学で解明できている範囲を知り、謙虚である。 天文学者の海部宣男氏は「何事も、100\%分か るようなものは面白くありませんね。子どもに とっても同じ。分からないことは恥ずかしいこ とでありません。僕は科学の話をするとき、『こ こまでが分かっていて、ここからは分からない』 とはっきり言います。どこからが分からないか をしっているのが科学者です。だから分からな いことの研究ができるのです。どういう謎が大 事なのか考えることができるのです。『何でも 知っている』という科学者がいたら、それはニ セモノです」(『Science Window』2007年10月 号) と話している。

何が分からない謎なのかを知れば、理科への 興味もさらに深まり、子どもたちの素朴な疑問
を一緒に解いていく気持ちになれるのではな いだろうか。

\section{科学コミュニケーターがつなぐ役割}

多くの雑誌、本の編集に携わる人たちが「科 学リテラシー」を身に付ける機会をこの報告書 をきっかけに創り出してほしい。理科系出身で 科学技術や環境問題の報道に携わって来た筆 者の一人 (佐藤) ですら、この「科学リテラシー」 で示され7分野すべてを学んではいない。高校 時代、知識を教え込む一辺倒の生物授業に辟易 した私（佐藤）の経験同様多くの編集者も自身 が受けた理科教育のなかで、何らかのつまずき を経験しているのではないだろうか。好奇心旺 盛で大活躍している科学記者の中には文系出 身者も多いのである。

マスメディアの組織内にあっては、科学技術 の知識のどこまでを常識として知っているべ きか、専門用語をどこまで使用するかが常に議 論になる。専門用語をどう市民の理解できる用 語に置き換えることができるのか。その意味で 科学分野の雑誌をつくるライターや新聞報道 に携わる人と報告書づくりに関わった研究者 との対話（コミュニケーション）が創出できれ ば素晴らしいに違いない。

科学コミュニケーションに携わる人だけで なく、学校の先生にこの報告書を読んでもらっ て意見を聞いてみたい。既に報告書を活用して 授業などに生かす研究をしている学校がある 
というので、いつかそれを取材して紹介したい

と思っている。子どもたちに科学を伝えていく という意味では科学コミュニケーターといえ る学校の先生たちの声を、報告書つくりにかか わった研究者に伝えることが私たちの役割で もあると考えている。

さらに『Science Window』では、報告書で 紹介している4つの話題（テーマ）を取り上げ、 生活者の視点で特集などを組んでみたいと考 えている。増刊号なども発行して、多くの方に 活用してもらうことはできないか。いろいろア イデイアが浮かぶが、プロジェクトにかかわっ た関係団体や学校教育関係者、サイエンスラ イター、科学コミュニケーターらと協力しな がら、科学リテラシーと科学コミュニケーショ ンの両輪をまわしていきたい。 